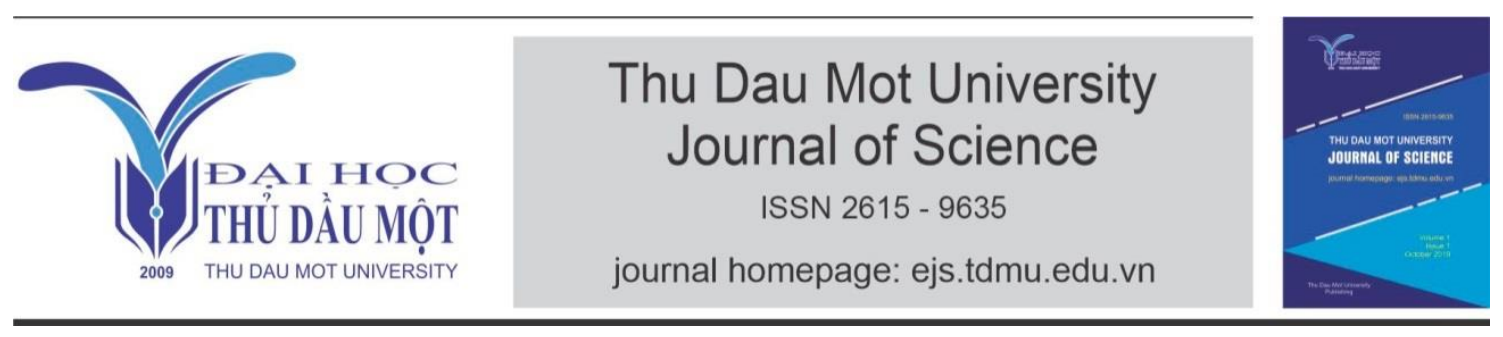

\title{
Monitoring supplied domestic water quality at Thu Dau Mot water supply enterprise
}

by Nguyễn Thanh Quang, Nguyễn Đặng Ngọc Giàu ( Thu Dau Mot University)

Article Info: Received 22 Feb. 2021, Accepted 1 Mar. 2021, Available online 15 Mar. 2021

Corresponding author: quangnt.mt@tdmu.edu.vn

https://doi.org/10.37550/tdmu.EJS/2021.01.148

\begin{abstract}
The current status assessment research of water use and quality of supplied domestic water in Thu Dau Mot city, Binh Duong province, as well as the clean water use situation of the local people. Sampling and assessment of the quality of supplied water at Thu Dau Mot Water supply enterprise. The water treatment process here is strictly conducted to ensure stability, constant pressure, inlet and outlet water flow.

The analysis results of physical and chemical parameters of water quality at Thu Dau Mot Water supply enterprise show parameters within the allowable limits of water standards for domestic use QCVN 02: 2009/BYT and domestic water QCVN 01: 2009/BYT. However, during the water treatment process in the rainy season, it is time consuming and costly for the use of many chemicals in the treatment process, as high turbidity and high color temperature, low TDS, low pH, low chloride, high SS, Fe and Mn content changes in the wet season higher than in the dry season. After sampling for analysis and treatment, the output water meets the clean water standard to meet the needs of the people in Thu Dau Mot City and surrounding areas.
\end{abstract}

Keywords: water quality, physical and chemical parameters, water standards, clean water 


\section{Introduction}

Water plays a very important role in maintaining life, as the most basic element in the developing process of human bodies, plants, animals and aquatic species, ... as well as industrial and agricultural activities. Based on the nature of water sources and arising sources, water can be divided into many types: surface water, groundwater, stormwater, mineral water, ... Water in nature often does not meet human requirements, so it needs to be treated before being used.

In recent years, Thu Dau Mot City has been under the pressure of a mechanical increase in the population, as the increase in industrial production, commerce and services, leading to increasing levels of serious environmental pollution, especially water source pollution. Therefore, the research and application of water treatment technologies contribute to the clean water supply for the people of the city and surrounding areas has been and has always been concerned by the authorities of Binh Duong Province.

\section{Research Methods}

\subsection{Research subjects}

Research by sampling raw water of Saigon River in Thu Dau Mot Water supply enterprise area based on TCVN 6663-6: 2008 (ISO 5667-6: 2005) and supplied water samples according to TCVN 5995: 1995 (ISO 5667-5: 1991). Sampling frequency is 5 times/day according to the time frames 7:30, 9:30, 11g, 14g and 16g.

Analysis of domestic parameters including sensory criteria (temperature, smell, taste and strange taste), basic parameters ( $\mathrm{pH}$, turbidity, color, TDS, residual chlorine), advanced index (chloride, acidity, alkalinity, total hardness, calcium hardness), nutritional criteria (nitrite, ammonium, phosphate, sulfate), metal index ( $\mathrm{Al}, \mathrm{Cu}, \mathrm{Fe}$, Nitrate, Manganese, $\mathrm{Zn}$ ).

\subsection{Process of water treatment technology at the plant}




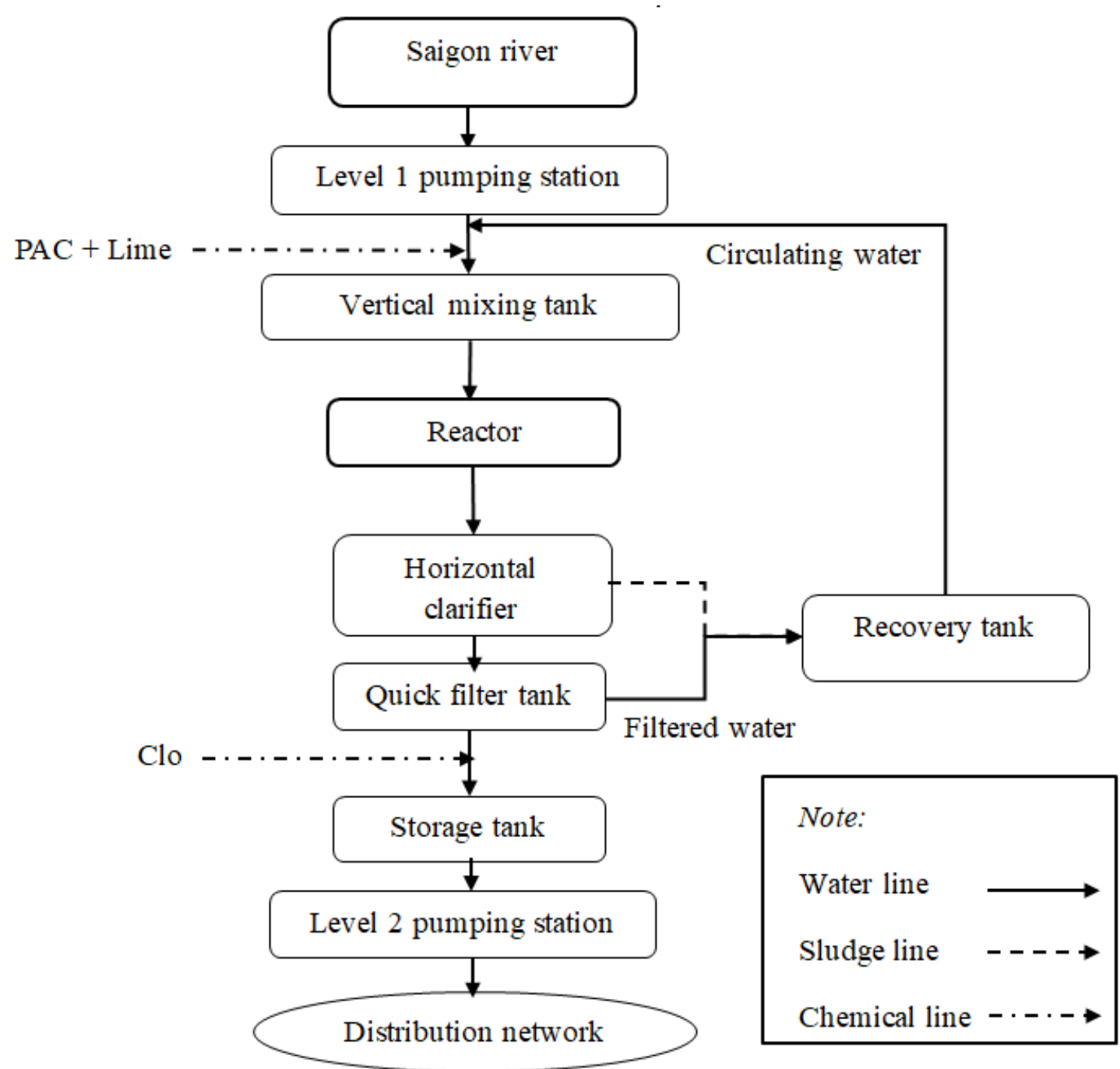

Chart 3.1. Chart of supplied water treatment technology for TDM water supply enterprise

\subsection{Testing facilities and equipment}

\subsubsection{Sampling raw water and water after being treated}

TABLE 1. Methods of sampling raw water and water after being treated

\begin{tabular}{|c|c|c|c|}
\hline $\begin{array}{l}\text { Sampling } \\
\text { locations }\end{array}$ & $\begin{array}{c}\text { Sampling } \\
\text { time }\end{array}$ & $\begin{array}{l}\text { Sampling } \\
\text { frequency }\end{array}$ & Method \\
\hline Raw water tank & $\begin{array}{c}7 \mathrm{~g} 30 \\
9 \mathrm{~g} 30 \\
11 \mathrm{~g} \\
14 \mathrm{~g} \\
16 \mathrm{~g}\end{array}$ & 5 times/day & \multirow{2}{*}{$\begin{array}{l}\text { A clean plastic or glass bottle must be labeled with } \\
\text { all details such as: } \\
\text { Name of water source, sampling time (hour, } \\
\text { date/month/year), sampling location, full name and } \\
\text { signature of sampling. }\end{array}$} \\
\hline $\begin{array}{c}\text { Water faucet } \\
\text { holds after being } \\
\text { treated }\end{array}$ & $\begin{array}{r}\mathrm{g} 30 \\
9 \mathrm{~g} 30 \\
11 \mathrm{~g}\end{array}$ & 5 times/day & \\
\hline
\end{tabular}




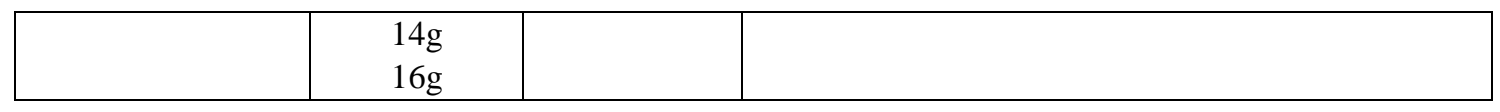

(Source: surveyor)

\subsubsection{Sampling, analyzing water quality}

\subsubsection{Sensory criteria}

Identifying temperature: Dip the electrode in the water sample to be measured. Turn on the thermometer and the temperature of the water sample to be measured appears on the monitor.

Identifying smell: How to determine water smell: Collect 100ml of water and put into a $250 \mathrm{ml}$ bottle, cover, shake the sample vigorously then open the lid and use your nose to determine water smell.

Identifying taste and strange taste: Put a little water to be tested in your mouth, little by little, do not swallow but keep in your mouth for 3 to 5 seconds to identify taste and strange taste.

\subsubsection{Some basic criteria}

Identifying $\mathrm{pH}$ : Use the standard solutions to check $\mathrm{pH}$ meter such as: Standard solution $\mathrm{pH}_{\text {standard }}=4, \mathrm{pH}_{\text {standard }}=7$. Wash the electrode with distilled water, dip it in the water sample to be measured. Turn on the device, $\mathrm{pH}$ of the water sample to be measured will appear on the screen of the meter.

Identifying turbidity: Rinse Cuvet thoroughly with distilled water, rinse with water to be measured. Put the water sample to be measured into the Cuvet. Use tissue to dry the outside, leaving no fingerprints or other marks to avoid errors. Put the Cuvet containing the sample in the Hach $2100 \mathrm{~N}$ Turbidimeter (turbidity detector), press the Enter button and receive the result.

Identifying color: Put $1.5 \mathrm{ml}$ of distilled water into a glass bottle then put in the Turbidimeter. Press zero to return the result. Then reject and add $1.5 \mathrm{ml}$ of water sample, press ENTER to get the result.

Identifying Total Water Dissolved Solids (TDS): Turn on the Turbidimeter and dip the Turbidimeter in the water sample, then get the results.

Identifying total residual chlorine (Orthotolidine method): Add Orthotolidine to a water sample in the ratio $1 / 9$ and shake well $(0.5 \mathrm{ml}$ of reagent in $9.5 \mathrm{ml}$ of water sample). Put $1 \mathrm{ml}$ of distilled water (blank) into a glass cup and put in Hach, press Zero to get zero results, then add $1 \mathrm{ml}$ of sample into the glass cup into the Turbidimeter, press Read to get the result.

\subsubsection{Some advanced criteria}


Identifying Acidity: Put $25 \mathrm{ml}$ of water sample into an erlen flask (if the raw water has to filter out turbidity), add 2-3 drops of Phenolphthalein indicator. Then metricize $0.02 \mathrm{~N}$ $\mathrm{NaOH}$ solution. The solution changes from colorless to light purple. Record V volume just metricized.

Identifying alkalinity: Take $25 \mathrm{ml}$ of water sample, place 3 indicator drops of Bromcresol Green in flask, metricized phenoltalein alkaline, and titrate with $0.02 \mathrm{~N}$ $\mathrm{H}_{2} \mathrm{SO}_{4}$ Acid. The solution changes from green to orange. Record the volume of Acid used in titration.

Identifying hardness:

(1) Total hardness: Put $25 \mathrm{ml}$ of sample in an erlen flask, and filter raw water. Then add 1 - $2 \mathrm{ml}$ of Ammonium Slurry solution (1 $\mathrm{ml}$ for tank water and $2 \mathrm{ml}$ for raw water) and add 1 tablespoon of EBT then shake well. Metricize with 0.01N EDTA solution. The color will change from acrid red to cyan. Record the metricized resulting volume of EDTA.

(2) Calcium hardness: Put $25 \mathrm{ml}$ of sample in an erlen flask, and filter raw water. Then add 3 to 5 drops of $12 \mathrm{~N} \mathrm{KOH} \mathrm{(3} \mathrm{drops} \mathrm{for} \mathrm{treated} \mathrm{water,} 5$ drops for raw water) and add a little Murexide and shake well. Metricize with 0.01N EDTA solution. The color will turn from pink to lilac purple. Record the metricized resulting volume of EDTA.

Identifying chloride (Morh method): Put $25 \mathrm{ml}$ of sample into an erlen flask, add 3 to 5 drops of $\mathrm{NaOH}+3$ drops of $\mathrm{K}_{2} \mathrm{CrO}_{4}$ (water turns light yellow), and metricize with $0.0141 \mathrm{~N} \mathrm{AgNO}_{3}$ standard solution that turns into orange from pale yellow. For identifying clearly, take a blank sample for comparison.

\subsubsection{Nutritional criteria}

Identifying Phosphate $\left(\mathrm{PO}_{4}{ }^{3-}\right)$ : Take $50 \mathrm{ml}$ of the sample and $50 \mathrm{ml}$ of distilled water (blank) add 2 ethers. Then add $2 \mathrm{ml}$ of Ammonium molybdate, shake well +5 drops of $\mathrm{SnCl}_{2}$ and shake well. Wait for 10 minutes to measure, press Read above to receive measurement results.

Identifying Ammonium in water $\left(\mathrm{NH}_{4}{ }^{+}\right.$) (direct Nesslerization method): Take $50 \mathrm{ml}$ of the sample and $50 \mathrm{ml}$ of distilled water (blank) add 2 ethers. Then add $2 \mathrm{ml}$ of Nessler and 1 drop of EDTA and shake well. Wait for 10 minutes to measure, press Read above to receive measurement results.

Identifying Sulfate $\left(\mathrm{SO}_{4}{ }^{2-}\right)$ (Measuring method of turbidity): If the sample is turbid, filter the quantitative filter paper that has been wet with water, and reject the first $20 \mathrm{ml}$ of filtrate. Take $25 \mathrm{ml}$ of the sample and $25 \mathrm{ml}$ of distilled water (blank) add 2 ethers. Then add $1 \mathrm{ml}$ of $\mathrm{MgCl}_{2}$ and a little of $\mathrm{BaCl}_{2}$ and shake until it is dissolved. Wait for 4 minutes to measure, press Read above to receive the measurement result. 
IdentifyingNitrite $\left(\mathrm{NO}_{2}{ }^{-}\right)$(Naphthylamine method): If the sample has high turbidity, it must be filtered by a centrifuge. Add $1 \mathrm{ml}$ of EDTA solution $+1 \mathrm{ml}$ of Sulfanilic Acid to $50 \mathrm{ml}$ of distilled water sample (blank sample) and $50 \mathrm{ml}$ of pure filtered sample, then shake, let stand for 3 minutes. Add $1 \mathrm{ml}$ of Naphthylamine $+1 \mathrm{ml}$ of Sodium Acetate filler to 2 samples, wait for 10 minutes to measure, press Read above to receive the measurement results.

Identifying nitrate content $\left(\mathrm{NO}_{3}{ }^{-}\right)$(Method 8039): If the sample is turbid, it should be filtered by a centrifuge. Lower $\mathrm{pH}=6-9$ by $\mathrm{NaOH}$. Add $10 \mathrm{ml}$ of water sample to ethylene as blank and add $10 \mathrm{ml}$ of water sample to another ethylene then add 1 pack of 5 Nitrate Nitratever, shake vigorously (still residue becomes suspended), the amber color will appear and wait for 5 minutes.

\subsubsection{Metal criteria. If the sample is turbid, it should be filtered by a centrifuge.}

Identifying aluminum content (Al): Lower $\mathrm{pH}$ to about $3.5-4.5$ by adding $\mathrm{NaOH}$. Add 1 pack of Ascorbic Acid to $50 \mathrm{ml}$ of water sample +1 pack of AluVer 3 reagent, shake unitl it is dissolved. Put $10 \mathrm{ml}$ of the chemically added sample to another ethylene and add 1 pack of Bleaching 3 to shake (as blank). Wait for 10-15 minutes measurement.

Identifying Iron ( $\mathrm{Fe}$ ) content (Method 8008): Lower $\mathrm{pH}$ to about 3-5 by adding $\mathrm{NaOH}$. Divide $20 \mathrm{ml}$ of the sample into 2 equal flasks into $10 \mathrm{ml}$ as the blank and $10 \mathrm{ml}$ as the real sample to take the test. The erlen flask contains $10 \mathrm{ml}$ of water as the blank without adding chemicals. Put 1 pack of FerroVer Iron reagent in an erlen flask containing 10 $\mathrm{ml}$ of the real sample, shake and wait for 3 minutes.

Identifying Manganese (Mn) content: Lower $\mathrm{pH}$ of $10 \mathrm{ml}$ of the filtered real sample to 4-5 with $\mathrm{NaOH}$. Add $10 \mathrm{ml}$ of distilled water into an erlen flask (as blank) and $10 \mathrm{ml}$ of water in another erlen flask as real sample. Add 1 pack of Ascorbic Acid to each flask, mix +12 drops of Alkaline Cyanide reagent, gently invert +12 drops of PAN $0.1 \%$ indicator, gently invert to avoid foaming. Orange color will appear if Manganese is present in the sample. Wait for 2 minutes to measure.

Identifying $(\mathrm{Cu})$ content: Put $20 \mathrm{ml}$ of the water sample into an erlen flask and Lower $\mathrm{pH}$ to about $4-5$ by adding $\mathrm{NaOH}$. Divide $20 \mathrm{ml}$ of the sample into 2 equal erlen flasks into $10 \mathrm{ml}$ as the blank and $10 \mathrm{ml}$ as the real sample to take the test. The erlen flask contains $10 \mathrm{ml}$ of water as the blank without adding chemicals. Put 1 pack of CuVer 1 Copper reagent into an erlen flask containing $10 \mathrm{ml}$ of the real sample, shake and allow to wait for 2 minutes. Press Hach Programs on the meter.

Identifying Zinc content (Zn): Put $20 \mathrm{ml}$ of the water sample into an erlen flask and Lower $\mathrm{pH}$ to about $4-5$ by adding $\mathrm{NaOH}$. Then add 1 sachet of Zincover $^{\mathrm{R}} 5$ to the flask, shake vigorously until it is dissolved, then put $10 \mathrm{ml}$ into another erlen flask and drip 
$0.5 \mathrm{ml}$ of Cycohexanone to wait for 2 minutes. The erlen flask contains the remaining $10 \mathrm{ml}$ of the sample as blank. Press Hach Programs on the meter.

\subsubsection{Jartest test}

\subsubsection{Test 1: Determine optimal pH}

Steps to take the test:

Step 1: Add 1 liter of raw water to each cup, then place the Jartest's paddle.

Step 2: Put the same PAC in the cup, depending on the turbidity of the water.

Step 3: Add to each cup a different amount of lime so that $\mathrm{pH}$ reaction reaches the predetermined $\mathrm{pH}$ value.

Step 4: Lower paddle, start the device and mix quickly for 1 minute at $120 \mathrm{rpm}$.

Step 5: After 1 minute, Lower stirring speed to $60 \mathrm{rpm}$ for 15 minutes. This is the reaction process.

Step 6: During the stirring reaction, observe the cotton residue, compare the size of the cotton residue formed, the cotton residue forming speed, the ability to flocculate in water.

Step 7: After 15 minutes, turn off the device and pull up the paddle and measure $\mathrm{pH}$ reaction.

Step 8: Wait for 10 minutes, observing the settling speed of each cup.

Step 9: Measure the turbidity and color temperature of each cup with the meter. Choose a cup with the lowest turbidity and coloration and a suitable $\mathrm{pH}$ range.

\subsubsection{Test 2: Identifying the optimal PAC}

Steps to take the test:

Step 1: Add 1 liter of raw water into each cup, then place it in Jartest's paddle.

Step 2: Add a different amount of PAC into each cup and increase gradually.

Step 3: Add lime evenly with the appropriate dosage to achieve the optimum $\mathrm{pH}$ value.

Step 4: Lower the paddle down, start the device and mix quickly for 1 minute at 120 rpm.

Step 5: After 1 minute, Lower stirring speed to $60 \mathrm{rpm}$ for 15 minutes. This is the reaction process.

Step 6: During the stirring reaction, observe the cotton residue, compare the size of the cotton residue formed, the cotton residue forming speed, the ability to flocculate in water.

Step 7: After 15 minutes, turn off the paddlewheel and measure $\mathrm{pH}$ reaction.

Step 8: Wait for 10 minutes, observing the settling speed of each cup. 
Step 9: Measure the turbidity and color temperature of each cup with the meter. Choose the cup with the lowest turbidity and coloration.

\section{Discussion results.}

The raw water used for the test is taken from Saigon River, the section flows through Thu Dau Mot city near Thu Dau Mot water treatment plant.

\subsection{Raw water test results analyzed by TDM water supply plant}

- Sample name: Water sample from Saigon River - Level 1 Thu Dau Mot pump station

- Sampling date: May 09th, 2020

- Sampling location: Level 1 pumping station - Thu Dau Mot Water supply enterprise

- Address: My Hao Hamlet, Chanh My Ward, Thu Dau Mot City, Binh Duong Province

- Analysis date: May $09^{\text {th }}, 2020$

- Sample status: Sample is taken at the time of high tide, containing an average of 2 liters, turbidity, yellow color, with sediment.

$T A B L E 2$. Test result table of raw water analyzed by TDM water supply enterprise

\begin{tabular}{|c|c|c|c|c|c|}
\hline No. & CRITERIA & UNIT & TEST METHOD & $\begin{array}{c}\text { QCVN 08- } \\
\text { MT:2015/BT } \\
\text { NMT (column } \\
\text { A2) }\end{array}$ & RESULT \\
\hline 1 & $\mathrm{pH}^{*}$ & - & TCVN 6492:2011 & $6,0-8,5$ & 6,62 \\
\hline 2 & $\begin{array}{l}\text { Dissolved oxygen content } \\
\text { (DO) }\end{array}$ & $\mathrm{mg} / \mathrm{L}$ & TCVN 7325:2004 & $\geq 5$ & 2,98 \\
\hline 3 & $\begin{array}{l}\text { Chemical oxygen content } \\
\text { (COD) }\end{array}$ & $\mathrm{mg} / \mathrm{L}$ & $\begin{array}{l}\text { SMEWW 5220- } \\
\text { C:2017 }\end{array}$ & $\leq 15$ & 16 \\
\hline 4 & $\begin{array}{l}\text { Biochemical oxygen } \\
\text { content }\left(\mathrm{BOD}_{5}\right)\end{array}$ & $\mathrm{mg} / \mathrm{L}$ & TCVN $6001-2: 2008$ & $\leq 6$ & 0,31 \\
\hline 5 & $\begin{array}{l}\text { Ammonium content } \\
\left(\mathrm{NH}_{4}^{+}\right)^{*}\end{array}$ & $\mathrm{mg} / \mathrm{L}$ & HACH Method 8038 & $\leq 0,3$ & 0,3 \\
\hline 6 & Nitrite content $\left(\mathrm{NO}_{2-}\right)^{*}$ & $\mathrm{mg} / \mathrm{L}$ & TCVN $6178-1996$ & $\leq 0,05$ & 0,04 \\
\hline 7 & Nitrate content $\left(\mathrm{NO}_{3}{ }^{-}\right)$ & $\mathrm{mg} / \mathrm{L}$ & $\begin{array}{c}\text { SMEWW 4500- } \\
\text { B:2017 }\end{array}$ & $\leq 5$ & 0,12 \\
\hline 8 & Phosphat content $\left(\mathrm{PO}_{4}{ }^{3-}\right)$ & $\mathrm{mg} / \mathrm{L}$ & $\begin{array}{l}\text { SMEWW 4500- } \\
\text { D:2017 }\end{array}$ & $\leq 0,2$ & 0,05 \\
\hline 9 & Total iron content $\left(\mathrm{Fe}_{\mathrm{tc}}\right)^{*}$ & $\mathrm{mg} / \mathrm{L}$ & HACH Method 8008 & $\leq 1$ & 0,19 \\
\hline 10 & Clorua content $\left(\mathrm{Cl}^{-}\right)^{*}$ & $\mathrm{mg} / \mathrm{L}$ & $\begin{array}{c}\text { SMEWW 4500- } \\
\text { B:2017 }\end{array}$ & $\leq 350$ & 19 \\
\hline 11 & Copper content $(\mathrm{Cu})$ & $\mathrm{mg} / \mathrm{L}$ & $\begin{array}{l}\text { HACH Method } 8506 \\
+8026\end{array}$ & $\leq 0,2$ & 0,01 \\
\hline 12 & Zinc content $(\mathrm{Zn})$ & $\mathrm{mg} / \mathrm{L}$ & HACH Method 8009 & $\leq 1,0$ & 0,02 \\
\hline 13 & Suspended solids (SS) & $\mathrm{mg} / \mathrm{L}$ & HACH Method 8006 & $\leq 30$ & 105 \\
\hline
\end{tabular}




\begin{tabular}{|c|l|c|c|c|c|}
\hline 14 & Manganese content $(\mathrm{Mn})^{*}$ & $\mathrm{mg} / \mathrm{L}$ & HACH Method 8149 & $\leq 0,2$ & 0,12 \\
\hline 15 & Sunphate content $\left(\mathrm{SO}_{4}{ }^{2-}\right)$ & $\mathrm{mg} / \mathrm{L}$ & $\begin{array}{c}\text { SMEWW 4500- } \\
\text { E:2017 }\end{array}$ & KQĐ & 47,4 \\
\hline 16 & Aluminum content $(\mathrm{Al})^{*}$ & $\mathrm{mg} / \mathrm{L}$ & HACH Method 8012 & KQĐ & 0,04 \\
\hline 17 & Total hardness & $\begin{array}{c}\mathrm{mg} / \mathrm{L} \\
\mathrm{CaCO}_{3}\end{array}$ & $\begin{array}{c}\text { SMEWW 2340- } \\
\text { C:2017 }\end{array}$ & KQĐ & 110 \\
\hline 18 & $\begin{array}{l}\text { Total dissolved solids } \\
\text { (TDS })\end{array}$ & $\mathrm{mg} / \mathrm{L}$ & Sensor probes & KQĐ & 102 \\
\hline 19 & Turbidity* & NTU & TCVN 6184:2008 & KQĐ & 80,6 \\
\hline 20 & Color temperature & Pt-Co & TCVN 6185:2008 & KQĐ & 474 \\
\hline 21 & Florua content $(\mathrm{F}) *$ & $\mathrm{mg} / \mathrm{L}$ & HACH Method 8029 & $\leq 1,5$ & KPH \\
\hline 22 & Xianua content & $\mathrm{mg} / \mathrm{L}$ & HACH Method 8027 & $\leq 0,05$ & 0,008 \\
\hline 23 & Cr & $\mathrm{mg} / \mathrm{L}$ & HACH Method 8023 & $\leq 0,02$ & 0,009 \\
\hline 24 & Niken content & $\mathrm{mg} / \mathrm{L}$ & HACH Method 8150 & $\leq 0,1$ & 0,009 \\
\hline 25 & Total oil, grease & $\mathrm{mg} / \mathrm{L}$ & ASTM D7066 - 04 & $\leq 0,5$ & KPH \\
\hline 26 & Total Coliform & $\begin{array}{c}\text { MPN/100 } \\
\mathrm{ml}\end{array}$ & TCVN 6187-2:1996 & $\leq 5000$ & 300 \\
\hline 27 & E. coli & $\begin{array}{c}\text { MPN/100 } \\
\mathrm{ml}\end{array}$ & TCVN 6187-2:1996 & $\leq 50$ & 240 \\
\hline
\end{tabular}

(Source: TDM water supply enterprise -2020)

* Comment: Water samples with DO, COD, SS, E. coli parameters are not conforming QCVN 08-MT: 2015/BTNMT (Column A2)

* Note:

+ QCVN 08-MT: 2015/BTNMT: National technical regulation on surface water quality.

+ KPH: Not detected; KQD: Not specified

+ Analysis results are only valid on the test sample at the time of testing

+ Sample storage time of 3 days from the date of giving the results

$+(*)$ : Criteria recognized by VILAS

\section{2. Raw water test results analyzed by the author.}

- Sample name: Water sample from Saigon River - Thu Dau Mot level 1 pump station

- Sampling date: November $29^{\text {th }}, 2020$

- Analysis date: November $29^{\text {th }}, 2020$

- Sampling location: Level 1 pumping station - Thu Dau Mot Water supply enterprise

- Address: My Hao Hamlet, Chanh My Ward, Thu Dau Mot City, Binh Duong Province.

Sample status: Sample is taken at the time of low tide, containing an average of 2 liters, turbidity, yellow color, with sediment.

Table 2. Test result table of raw water analyzed by author 


\begin{tabular}{|c|c|c|c|c|c|}
\hline No. & CRITERIA & UNIT & TEST METHOD & $\begin{array}{c}\text { QCVN 08- } \\
\text { MT:2015/BT } \\
\text { NMT (column } \\
\text { A2) }\end{array}$ & RESULT \\
\hline 1 & $\mathrm{pH}^{*}$ & - & TCVN 6492:2011 & $6,0-8,5$ & 6,96 \\
\hline 2 & $\begin{array}{l}\text { Dissolved oxygen } \\
\text { content (DO) }\end{array}$ & $\mathrm{mg} / \mathrm{L}$ & TCVN 7325:2004 & $\geq 5$ & 2,11 \\
\hline 3 & $\begin{array}{l}\text { Chemical oxygen } \\
\text { content }(\mathrm{COD})\end{array}$ & $\mathrm{mg} / \mathrm{L}$ & $\begin{array}{l}\text { SMEWW 5220- } \\
\text { C:2017 }\end{array}$ & $\leq 15$ & 24 \\
\hline 4 & $\begin{array}{l}\text { Biochemical oxygen } \\
\text { content }\left(\mathrm{BOD}_{5}\right)\end{array}$ & $\mathrm{mg} / \mathrm{L}$ & TCVN $6001-2: 2008$ & $\leq 6$ & 0,71 \\
\hline 5 & $\begin{array}{l}\text { Ammonium content } \\
\left(\mathrm{NH}_{4}^{+}\right)^{*}\end{array}$ & $\mathrm{mg} / \mathrm{L}$ & HACH Method 8038 & $\leq 0,3$ & 1,2 \\
\hline 6 & Nitrite content $\left(\mathrm{NO}_{2-}\right)^{*}$ & $\mathrm{mg} / \mathrm{L}$ & TCVN $6178-1996$ & $\leq 0,05$ & 0,02 \\
\hline 7 & Nitrate content $\left(\mathrm{NO}_{3}^{-}\right)$ & $\mathrm{mg} / \mathrm{L}$ & $\begin{array}{l}\text { SMEWW 4500- } \\
\text { B:2017 }\end{array}$ & $\leq 5$ & 0,55 \\
\hline 8 & $\begin{array}{l}\text { Phosphat content }\left(\mathrm{PO}_{4}{ }^{3-}\right. \\
\text { ) }\end{array}$ & $\mathrm{mg} / \mathrm{L}$ & $\begin{array}{l}\text { SMEWW 4500- } \\
\text { D:2017 }\end{array}$ & $\leq 0,2$ & 0,04 \\
\hline 9 & $\begin{array}{l}\text { Total iron content } \\
\left(\mathrm{Fe}_{\mathrm{tc}}\right)^{*}\end{array}$ & $\mathrm{mg} / \mathrm{L}$ & HACH Method 8008 & $\leq 1$ & 0,39 \\
\hline 10 & Clorua content $\left(\mathrm{Cl}^{-}\right)^{*}$ & $\mathrm{mg} / \mathrm{L}$ & $\begin{array}{l}\text { SMEWW 4500- } \\
\text { B:2017 }\end{array}$ & $\leq 350$ & 227 \\
\hline 11 & Copper content $(\mathrm{Cu})$ & $\mathrm{mg} / \mathrm{L}$ & $\begin{array}{l}\text { HACH Method } 8506+ \\
8026\end{array}$ & $\leq 0,2$ & 0,03 \\
\hline 12 & Zinc content (Zn) & $\mathrm{mg} / \mathrm{L}$ & HACH Method 8009 & $\leq 1,0$ & 0,02 \\
\hline 13 & Suspended solids (SS) & $\mathrm{mg} / \mathrm{L}$ & HACH Method 8006 & $\leq 30$ & 93 \\
\hline 14 & $\begin{array}{l}\text { Manganese content } \\
(\mathrm{Mn})^{*}\end{array}$ & $\mathrm{mg} / \mathrm{L}$ & HACH Method 8149 & $\leq 0,2$ & 0,15 \\
\hline 15 & Sunphate content $\left(\mathrm{SO}_{4}{ }^{2-}\right.$ & $\mathrm{mg} / \mathrm{L}$ & $\begin{array}{l}\text { SMEWW 4500- } \\
\text { E:2017 }\end{array}$ & KQĐ & 41,28 \\
\hline 16 & $\begin{array}{l}\text { Aluminum content } \\
\text { (Al)* }\end{array}$ & $\mathrm{mg} / \mathrm{L}$ & HACH Method 8012 & KQĐ & 0,06 \\
\hline 17 & Total hardness & $\begin{array}{c}\mathrm{mg} / \mathrm{L} \\
\mathrm{CaCO}_{3}\end{array}$ & $\begin{array}{l}\text { SMEWW 2340- } \\
\text { C:2017 }\end{array}$ & KQĐ & 25,3 \\
\hline 18 & $\begin{array}{l}\text { Total dissolved solids } \\
\text { (TDS) }\end{array}$ & $\mathrm{mg} / \mathrm{L}$ & Sensor probes & KQĐ & 505 \\
\hline 19 & Turbidity* & NTU & TCVN 6184:2008 & KQĐ & 80,3 \\
\hline 20 & Color temperature & Pt-Co & TCVN 6185:2008 & KQĐ & 374 \\
\hline
\end{tabular}




\begin{tabular}{|c|l|c|c|c|c|}
\hline 21 & Florua content $(\mathrm{F})^{*}$ & $\mathrm{mg} / \mathrm{L}$ & HACH Method 8029 & $\leq 1,5$ & $\mathrm{KPH}$ \\
\hline 22 & Xianua content & $\mathrm{mg} / \mathrm{L}$ & HACH Method 8027 & $\leq 0,05$ & 0,004 \\
\hline 23 & $\mathrm{Cr}^{6+}$ & $\mathrm{mg} / \mathrm{L}$ & HACH Method 8023 & $\leq 0,02$ & 0,004 \\
\hline 24 & Niken content & $\mathrm{mg} / \mathrm{L}$ & HACH Method 8150 & $\leq 0,1$ & 0,005 \\
\hline 25 & Total oil, grease & $\mathrm{mg} / \mathrm{L}$ & ASTM D7066 - 04 & $\leq 0,5$ & $\mathrm{KPH}$ \\
\hline 26 & Total Coliform & $\begin{array}{c}\text { MPN/100m } \\
1\end{array}$ & TCVN 6187-2:1996 & $\leq 5000$ & 1.400 \\
\hline 27 & E. coli & $\begin{array}{c}\text { MPN/100m } \\
1\end{array}$ & TCVN 6187-2:1996 & $\leq 50$ & 1.1000 \\
\hline
\end{tabular}

(Source: author anlysis-2020)

* Comment: Water samples with DO, COD, $\mathrm{NH}_{4}{ }^{+}$, $-\mathrm{N}, \mathrm{SS}$, E. coli parameters are not conforming QCVN 08-MT: 2015/BTNMT (Column A2)

* Note:

+ QCVN 08-MT: 2015/BTNMT: National technical regulation on surface water quality.

+ KPH: Not detected. KQD: Not specified

Analysis results are only valid on the test sample at the time of testing

+ Sample storage time 3 days from the date of giving the results

$+(*)$ : Criteria recognized by VILAS

\subsection{Test result of treated water analyzed by TDM plant.}

- Sample name: Treated water - Thu Dau Mot tank

- Address: My Hao Hamlet, Chanh My Ward, Thu Dau Mot City, Binh Duong Province.

- Sampling date: May $09^{\text {th }}, 2020$

- Analysis date: May $09^{\text {th }}, 2020$

- Sample status: Sample is collected in 2 1-liter bottles. The water sample is clear, colorless, no strange smell.

Table 3. Test result table of treated water analyzed by TDM water supply enterprise

\begin{tabular}{|c|l|c|c|c|c|}
\hline No. & \multicolumn{1}{|c|}{$\begin{array}{c}\text { ANALYSIS } \\
\text { CRITERIA }\end{array}$} & UNIT & TEST METHOD & $\begin{array}{c}\text { QCVN } \\
\text { 01:2009/BYT }\end{array}$ & $\begin{array}{c}\text { TEST } \\
\text { RESULT }\end{array}$ \\
\hline 1 & $\mathrm{pH}^{*}$ & - & TCVN 6492:2011 & $6,5-8,5$ & 7,14 \\
\hline 2 & Flavor & - & Sensory & $\begin{array}{c}\text { Tasteless, } \\
\text { scentless }\end{array}$ & $\begin{array}{c}\text { Tasteless, } \\
\text { scentless }\end{array}$ \\
\hline 3 & $\begin{array}{l}\text { Total Dissolved Solids } \\
\text { (TDS) }\end{array}$ & $\mathrm{mg} / \mathrm{L}$ & Sensor probes & $\leq 1000$ & 313 \\
\hline 4 & Turbidity* & NTU & TCVN 6184:2008 & $\leq 2$ & 0,28 \\
\hline
\end{tabular}




\begin{tabular}{|c|c|c|c|c|c|}
\hline 5 & Color & Pt-Co & TCVN 6185:2008 & $\leq 15$ & 2 \\
\hline 6 & Total Hardness & $\begin{array}{c}\mathrm{mg} / \mathrm{L} \\
\mathrm{CaCO}_{3}\end{array}$ & $\begin{array}{l}\text { SMEWW 2340- } \\
\text { C:2017 }\end{array}$ & $\leq 300$ & 84 \\
\hline 7 & Chloride Content $\left(\mathrm{Cl}^{-}\right)^{*}$ & $\mathrm{mg} / \mathrm{L}$ & $\begin{array}{l}\text { SMEWW 4500- } \\
\text { B:2017 }\end{array}$ & $\leq 250$ & 141,8 \\
\hline 8 & Residual Chlorine & $\mathrm{mg} / \mathrm{L}$ & $\begin{array}{l}\text { SMEWW 4500- } \\
00 \mathrm{Cl}: 2017\end{array}$ & $0,3-0,5$ & 0,5 \\
\hline 9 & $\begin{array}{l}\text { Ammonium content } \\
\left(\mathrm{NH}_{4}^{+}\right)^{*}\end{array}$ & $\mathrm{mg} / \mathrm{L}$ & HACH Method 8038 & $\leq 3$ & 0,06 \\
\hline 10 & Nitrite content $\left(\mathrm{NO}_{2}{ }^{-}\right)^{*}$ & $\mathrm{mg} / \mathrm{L}$ & TCVN 6178-1996 & $\leq 3$ & $\begin{array}{c}\mathrm{KPH} \\
\text { (LOD: } \\
0,03 \\
\mathrm{mg} / \mathrm{L} \text { ) }\end{array}$ \\
\hline 11 & Nitrate content $\left(\mathrm{NO}_{3}^{-}\right)$ & $\mathrm{mg} / \mathrm{L}$ & $\begin{array}{l}\text { SMEWW 4500- } \\
\text { B:2017 }\end{array}$ & $\leq 50$ & 0,21 \\
\hline 12 & $\begin{array}{l}\text { Sunphate content }\left(\mathrm{SO}_{4}{ }^{2-}\right. \\
\end{array}$ & $\mathrm{mg} / \mathrm{L}$ & $\begin{array}{l}\text { SMEWW 4500- } \\
\text { E:2017 }\end{array}$ & $\leq 250$ & 38,28 \\
\hline 13 & $\begin{array}{l}\text { Total iron content } \\
\left(\mathrm{Fe}_{\mathrm{tc}}\right)^{*}\end{array}$ & $\mathrm{mg} / \mathrm{L}$ & HACH Method 8008 & $\leq 0,3$ & 0,02 \\
\hline 14 & Aluminum content $(\mathrm{Al})^{*}$ & $\mathrm{mg} / \mathrm{L}$ & HACH Method 8012 & $\leq 0,2$ & 0,04 \\
\hline 15 & Copper content $(\mathrm{Cu})$ & $\mathrm{mg} / \mathrm{L}$ & $\begin{array}{l}\text { HACH Method } 8506 \\
+8026\end{array}$ & $\leq 1$ & 0,01 \\
\hline 16 & Zinc content (Zn) & $\mathrm{mg} / \mathrm{L}$ & HACH Method 8009 & $\leq 3$ & 0,01 \\
\hline 17 & $\begin{array}{l}\text { Manganese content } \\
(\mathrm{Mn})^{*}\end{array}$ & $\mathrm{mg} / \mathrm{L}$ & HACH Method 8149 & $\leq 0,3$ & 0,02 \\
\hline 18 & Pecmanganate index* & $\mathrm{mgO}_{2} / \mathrm{L}$ & TCVN 6186:1996 & $\leq 2$ & 0,77 \\
\hline 19 & $\begin{array}{l}\text { Phosphate content } \\
\left(\mathrm{PO}_{4}^{3-}\right)\end{array}$ & $\mathrm{mg} / \mathrm{L}$ & $\begin{array}{c}\text { SMEWW 4500- } \\
\text { D:2017 }\end{array}$ & KQĐ & 0,01 \\
\hline 20 & Total Coliform & $\begin{array}{c}\mathrm{CFU} / 100 \mathrm{~m} \\
\mathrm{~L}\end{array}$ & TCVN 6187-1:2019 & 0 & 0 \\
\hline 21 & E. Coli & $\begin{array}{c}\mathrm{CFU} / 100 \mathrm{~m} \\
\mathrm{~L}\end{array}$ & TCVN 6187-1:2019 & 0 & 0 \\
\hline
\end{tabular}

(Source: TDM water supply enterprise -2020)

* Comment: Water samples have suitable analytical parameters QCVN 01: 2009/BYT

* Note:

+ QCVN 01: 2009/BYT: National technical regulation on domestic water quality

Analysis results are only valid on the test sample at the time of testing

$+\mathrm{KPH}:$ Not detected

+ KQD: Not specified

+ Sample storage time 3 days from the date of giving the results

$+(*)$ : Criteria recognized by VILAS

3.4. Test results of water after being treated are analyzed by the author. 
- Sample name: Treated water - Thu Dau Mot tank

- Address: My Hao Hamlet, Chanh My Ward, Thu Dau Mot City, Binh Duong Province

- Sampling date: November $29^{\text {th }}, 2020$

- Analysis date: November $29^{\text {th }}, 2020$

Sample status: Sample is collected in 2 1-liter bottles. The water sample is clear, colorless, no strange smell.

TABLE 4. Test result table of treated water analyzed by the author

\begin{tabular}{|c|c|c|c|c|c|}
\hline No. & $\begin{array}{l}\text { ANALYSIS } \\
\text { CRITERIA }\end{array}$ & UNIT & TEST METHOD & $\begin{array}{c}\text { QCVN } \\
01: 2009 / B Y \\
T\end{array}$ & $\begin{array}{c}\text { TEST } \\
\text { RESULT }\end{array}$ \\
\hline 1 & $\mathrm{pH}^{*}$ & - & TCVN 6492:2011 & $6,5-8,5$ & 7,21 \\
\hline 2 & Flavor & - & Sensory & $\begin{array}{l}\text { Tasteless, } \\
\text { scentless }\end{array}$ & $\begin{array}{l}\text { Tasteless, } \\
\text { scentless }\end{array}$ \\
\hline 3 & $\begin{array}{l}\text { Total Dissolved Solids } \\
\text { (TDS) }\end{array}$ & $\mathrm{mg} / \mathrm{L}$ & Sensor probes & $\leq 1000$ & 120 \\
\hline 4 & Turbidity* & NTU & TCVN 6184:2008 & $\leq 2$ & 0,28 \\
\hline 5 & Color & Pt-Co & TCVN 6185:2008 & $\leq 15$ & 2 \\
\hline 6 & Total Hardness & $\begin{array}{c}\mathrm{mg} / \mathrm{L} \\
\mathrm{CaCO}_{3}\end{array}$ & $\begin{array}{l}\text { SMEWW 2340- } \\
\text { C:2017 }\end{array}$ & $\leq 300$ & 53,5 \\
\hline 7 & Chloride Content $\left(\mathrm{Cl}^{-}\right)^{*}$ & $\mathrm{mg} / \mathrm{L}$ & $\begin{array}{l}\text { SMEWW 4500- } \\
\text { B:2017 }\end{array}$ & $\leq 250$ & 25 \\
\hline 8 & Residual Chlorine & $\mathrm{mg} / \mathrm{L}$ & $\begin{array}{l}\text { SMEWW 4500- } \\
\text { 00Cl:2017 }\end{array}$ & $0,3-0,5$ & 0,42 \\
\hline 9 & $\begin{array}{l}\text { Ammonium content } \\
\left(\mathrm{NH}_{4}^{+}\right)^{*}\end{array}$ & $\mathrm{mg} / \mathrm{L}$ & HACH Method 8038 & $\leq 3$ & 0,17 \\
\hline 10 & Nitrite content $\left(\mathrm{NO}_{2}^{-}\right)^{*}$ & $\mathrm{mg} / \mathrm{L}$ & TCVN 6178-1996 & $\leq 3$ & $\begin{array}{c}\text { KPH } \\
\text { (LOD: } 0,03 \\
\text { mg/L) }\end{array}$ \\
\hline 11 & Nitrate content $\left(\mathrm{NO}_{3}^{-}\right)$ & $\mathrm{mg} / \mathrm{L}$ & $\begin{array}{l}\text { SMEWW 4500- } \\
\text { B:2017 }\end{array}$ & $\leq 50$ & 4,18 \\
\hline 12 & $\begin{array}{l}\text { Sunphate content } \\
\left(\mathrm{SO}_{4}^{2-}\right)\end{array}$ & $\mathrm{mg} / \mathrm{L}$ & $\begin{array}{c}\text { SMEWW 4500- } \\
\text { E:2017 } \\
\end{array}$ & $\leq 250$ & 30,15 \\
\hline 13 & $\begin{array}{l}\text { Total iron content } \\
\left(\mathrm{Fe}_{\mathrm{tc}}\right)^{*}\end{array}$ & $\mathrm{mg} / \mathrm{L}$ & HACH Method 8008 & $\leq 0,3$ & 0,02 \\
\hline 14 & $\begin{array}{l}\text { Aluminum content } \\
(\mathrm{Al}) *\end{array}$ & $\mathrm{mg} / \mathrm{L}$ & HACH Method 8012 & $\leq 0,2$ & 0,07 \\
\hline 15 & Copper content $(\mathrm{Cu})$ & $\mathrm{mg} / \mathrm{L}$ & $\begin{array}{l}\text { HACH Method } 8506 \\
+8026\end{array}$ & $\leq 1$ & 0,01 \\
\hline 16 & Zinc content $(\mathrm{Zn})$ & $\mathrm{mg} / \mathrm{L}$ & HACH Method 8009 & $\leq 3$ & 0,03 \\
\hline 17 & $\begin{array}{l}\text { Manganese content } \\
(\mathrm{Mn})^{*}\end{array}$ & $\mathrm{mg} / \mathrm{L}$ & HACH Method 8149 & $\leq 0,3$ & 0,03 \\
\hline 18 & Pecmanganate index* & $\mathrm{mgO}_{2} / \mathrm{L}$ & TCVN 6186:1996 & $\leq 2$ & 0,64 \\
\hline
\end{tabular}




\begin{tabular}{|c|l|c|c|c|c|}
\hline 19 & $\begin{array}{l}\text { Phosphate content } \\
\left(\mathrm{PO}_{4}{ }^{3-}\right)\end{array}$ & $\mathrm{mg} / \mathrm{L}$ & $\begin{array}{c}\text { SMEWW 4500- } \\
\text { D:2017 }\end{array}$ & KQĐ & 0,01 \\
\hline 20 & Total Coliform & CFU/100mL & TCVN 6187-1:2019 & 0 & 0 \\
\hline 21 & E. Coli & CFU/100mL & TCVN 6187-1:2019 & 0 & 0 \\
\hline
\end{tabular}

(Source: author anlysis-2020)

* Comment: Water samples have suitable analytical parameters QCVN 01: 2009/BYT

* Note:

+ QCVN 01: 2009/BYT: National technical regulation on domestic water quality

+ Analysis results are only valid on the test sample at the time of testing

+ KPH: Not detected; KQD: Not specified

+ Sample storage time 3 days from the date of giving the results

$+(*)$ : Criteria recognized by VILAS

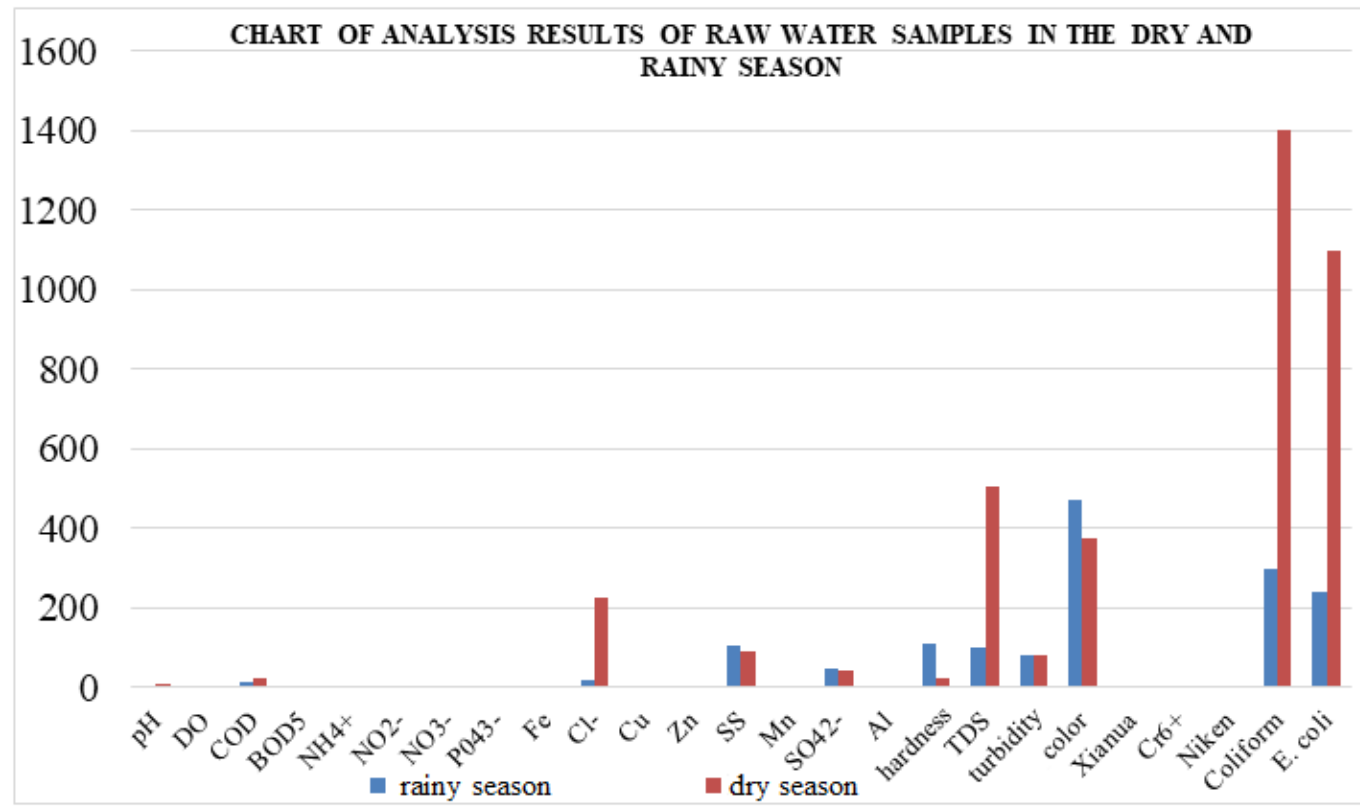

Figure 1. Chart of raw water sample analysis results in the dry and rainy season

* Comment: The chart shows that raw water samples treated in the rainy season will take more time and consume more chemical as high water turbidity, low TDS, low pH, high color, low chloride content, low SS (depending on high or low tide) in the rainy season, ... compared to water sample treatment in the dry season.

\section{Conclusion}

Thu Dau Mot plant is treating water according to QCVN 01: 2009/BYT on output water quality. Currently, the water treatment plant has applied lamen plates in clarifiers to 
increase sedimentation ability to achieve high efficiency. The tested water quality shows that it is within the allowable limits of QCVN 01: 2009/BYT National technical regulation on domestic water quantity.

Currently, the plant has developed the instructions for safe operating procedures and troubleshooting instructions when it is necessary. There is always a timely response plan to ensure the quality of the outlet water meets the standards of the Ministry of Health.

The plant regularly takes samples and checks the parameters in the samples in order to detect and notify the technical department of problems arising in the input water treatment process to promptly take the good resolution.

The operating process is carried out by engineers specialized in environment, electricity and automation with high expertise and enthusiasm in water treatment to provide domestic water to the people in the area.

The water treatment works are designed and built reasonably in the plant campus, ensuring efficient water treatment as well as the general landscape.

\section{References}

Nguyen Ngoc Dung (2009). Water treatment. Construction Publishing House.

Phan anh Duc, Nguyen Thi Mai Linh (2015). Environmental quality monitoring. Construction Publishing House.

Le Quoc Hung (2006). Methods and equipment for water environment monitoring. Publisher of Vietnam Academy of Science and Technology.

Bui Phuong Linh, Le Hoang Nghiem (2019). Methods of analyzing parameters of environmental monitoring. Ho Chi Minh City National University Publisher.

Nguyen Van Phuoc, Nguyen Thi Van Ha (2006). Environmental quality management. Construction Publishing House.

Nguyen Thi Thu Thuy (2000). Water treatment for domestic and industrial purposes. Science and Technology Publishing House. 